\title{
Fernando Binvitnat
}

\section{Poemas de La Luna de Oro}

\section{NOCTURNO 、}

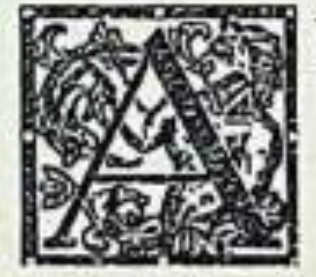

NCLA la noche en la ciudad su navío de sombra y de misterio. Velero gigante de leyendas románticas, fabuloso velero,

que viene de las islas

divinas del ensueño.

En sus bodegas grises

guarda el tesoro de los soles muertos

y la riqueza incomparable

de los crepúsculos de Enero.

En sus mástiles azules

las estrellas son faroles geométricos

y en el palo mayor la luna llena

es un farol inmenso,

y cuando se hace al mar,

se hincha como dos alas el velamen del cielo. 
Viene todos los días

cuando la tarde extingue sus incendios sobre las viejas montañas.

Entonces la ciudad como un puerto se llena de luces y de rumor de mar.

La noche atraca su velero.

Los poetas y los vagabundos

son sus marineros.

Su capitán

es el silencio. 